\title{
Probabilistic snow cover and ensemble streamflow estimations in the Upper Euphrates Basin
}

\author{
A. Arda Şorman*, Gökçen Uysal, Aynur Şensoy \\ Department of Civil Engineering, Anadolu University, 26555, Eskişehir, Turkey. E-mails: gokcenuysal@anadolu.edu.tr, \\ asensoy@anadolu.edu.tr \\ * Corresponding author. Tel.: +90-222-3213550/6612. Fax: +90-222-3239501. E-mail: asorman@anadolu.edu.tr
}

\begin{abstract}
Predicting snow cover dynamics and relevant streamflow due to snowmelt is a challenging issue in mountainous basins. Spatio-temporal variations of snow extent can be analyzed using probabilistic snow cover maps derived from satellite images within a relatively long period. In this study, Probabilistic Snow Depletion Curves (P-SDCs) and Probabilistic Snow Lines (P-SLs) are acquired from Moderate Resolution Imaging Spectroradiometer (MODIS) cloud-filtered daily snow cover images. Analyses of P-SDCs show a strong correlation with average daily runoff $\left(\mathrm{R}^{2}=0.90\right)$ and temperature $\left(\mathrm{R}^{2}=0.96\right)$. On the other hand, the challenge lies in developing noteworthy methods to use P-SDCs in streamflow estimations. Therefore, the main objective is to explore the feasibility of producing probabilistic runoff forecasts with P-SDC forcing in a snow dominated basin.

Upper Euphrates Basin in Turkey has large snow extent and high snowmelt contribution during spring and summer periods. The melting characteristics are defined by P-SDCs using MODIS imagery for 2001-2012. The value of snow probability maps on ensemble runoff predictions is shown with Snowmelt Runoff Model (SRM) during 2013-2015 where the estimated runoff values indicate good consistency (NSE: 0.47-0.93) with forecasts based on the derived P-SDCs. Therefore, the probabilistic approach distinguishes the snow cover characteristics for a region and promotes a useful methodology on the application of probabilistic runoff predictions especially for snow dominated areas.
\end{abstract}

Keywords: Euphrates River Basin; MODIS; Probabilistic snow maps; Hydrological modeling; Ensemble streamflow estimation.

\section{INTRODUCTION}

Snow is an essential component in hydrological cycle particularly for mountainous regions and accumulated snow plays a crucial role during melting season in terms of water supply, hydropower generation, flood control, irrigation and avalanche research. However, estimation of potential snowpack and its contribution to streamflow is challenging due to complex physics of snowmelt and harsh topographic conditions in these regions. Snow cover is an important indicator of the climatic character of winter and spring (Krajci et al., 2016). Thus, assessment of snow cover dynamics at catchment scale helps to better understand the changes in flood regimes and improve snowmelt runoff forecasting. Due to the limitation in sparse observation network particularly for the mountainous regions, spatial patterns and seasonal depletion of snow cover is more easily monitored by multi spectral remote sensing.

Among the variety of satellites, MODIS (Moderate Resolution Imaging Spectroradiometer), with visible/near-infrared satellite sensors on Terra and Aqua platforms, provides processed Snow Cover Area (SCA) products since early 2000s. Numerous global and regional studies have been conducted on validation of MODIS snow data to identify snow mapping accuracy (Arsenault et al., 2014; Crawford, 2015; Hall and Riggs, 2007; Huang et al., 2011; Maurer et al., 2003; Parajka and Blöschl, 2008; Raleigh et al., 2013; Riggs et al., 2006; Tekeli et al., 2005; Wang et al., 2009). MODIS data have been successfully applied in snowmelt modeling (Day, 2013; Duethmann et al., 2014; Finger et al., 2015; Franz and Karsten, 2013; He et al., 2014; Li and Williams, 2008; Parajka and Blöschl, 2008; Şensoy and Uysal, 2012; Şorman et al., 2009) or in hydro-climatological and topographic research of snow cover variations (Cornwell et al., 2016; Forsythe et al., 2012; Gascoin et. al., 2015; Singh et al., 2003; Tang et.al., 2013; Tong et al., 2009; Wang and Xie, 2009). Moreover, various researchers attempted to apply different algorithms to decrease cloud coverage of MODIS products (Da Ronco and De Michele, 2014; Gafurov and Bárdossy, 2009; Gao et al., 2010; Krajčí et al., 2014; Parajka and Blöschl, 2008; Parajka et al., 2010; Sorman and Yamankurt, 2011).

Probability analysis of satellite snow cover data with relatively long and continuous records would be beneficial for analysis of snow climatology and operational snowmelt runoff forecasting. However there are limited studies associated with it in literature. Brander et al. (2000) derived snow cover duration maps using a limited number of Landsat-TM imagery. Richer (2009) derived snow probability maps for a basin in Colorado, using 8-day snow cover products of MODIS for the melting periods of 2000-2006 and investigated spatial and temporal snow distribution trends. Şensoy and Uysal (2012) presented the probability approach in snow depletion forecasting with a limited number of MODIS snow cover data. López-Burgos et al. (2013) used the locally-weighted logistic regression (LWLR) method to estimate probabilistic snow occurrences for developing the cloud removal technique. Gafurov et al. (2015) presented a methodology mainly based on correlations between station records and spatial snow-cover patterns, for reconstructing past snow cover using historical in situ snow-depth data, remote sensing snow-cover data and topographic data. Recently, Tekeli et al. (2016) calculated snow probability maps using Interactive Multi Sensor Snow and Ice Mapping System (IMS) snow products over Turkey. The work was accomplished with lower spatial resolution images, and only the validation methodology was discussed with ground measurements. On the overall, the elaborated studies are either limited on the number/time resolution of snow cover data or their implementation 
within any hydrological modeling context are poorly addressed in terms of probabilistic studies.

Improved techniques in hydrological modeling studies may reveal the quantification of knowledge on long-term probabilistic snow cover extent and create an added value for water resources management. SCA can be examined both temporally and spatially with daily snow depletion curves (SDCs) which designate the snow coverage on each day of the melt season. One of the well-known conceptual models is Snowmelt Runoff Model (SRM) which enables to use SDCs as the main variable of snowmelt modeling for mountainous basins applied to several catchments around the world (Gómez-Landesa and Rango, 2002; Jain et al., 2010a; Jain et al., 2010b; Lee et al., 2005; Martinec, 1975; Panday et al., 2014; Şensoy and Uysal, 2012; Sensoy et al., 2014a; Sensoy et al., 2014b; Tahir et al., 2011; Tekeli et al., 2005). On the other hand, estimation of SCA is still a challenging issue in operational runoff forecasting.

Snow plays an important role in the hydrological regime, operational applications and climatic processes for the headwaters of transboundary Euphrates River as in many other mountainous regions. The Upper Euphrates River Basin is a highly snow-dominated area where snowmelt constitutes approximately $2 / 3$ of total annual volume during spring and early summer months. Therefore, one of the headwater basins of the Euphrates River is selected as a pilot basin in this study with 10275 $\mathrm{km}^{2}$ area. Concerning the harsh environmental conditions, the extent of the area and relatively scarce observation network, satellite remote sensing provides the most suitable method of monitoring snow variations over the region with a diversity of temporal and spatial scales. Even though particularly important, it is still a less-studied region of the world to extract and assess the snow cover characteristics using satellite technology.

Building upon the previous accuracy assessment and modeling studies (Şorman et al., 2007; Şorman et al., 2009; Tekeli et al., 2005) the work presented here provides the probabilistic appraisal of reliable snow cover monitoring by taking the advantage of long-term, continuous observations of MODIS SCA data over the mountainous headwaters of Euphrates River. The main purpose of the study is to derive daily probabilistic snow cover extent and characteristic snow depletion curves (P-SDCs) with corresponding Probabilistic Snow Line (P-SL) using a relatively long period of (12 years) daily cloud-filtered MODIS snow cover data for the area of interest, and also to investigate the possible relations with P-SDC and hydro-meteorological variables. Moreover, the main contribution herein is to present a noteworthy methodology to produce Probabilistic Ensemble Streamflow Forecasts (P-ESF) with P-SDC forcing into a hydrological model for a snow dominated data scarce headwater region of the Euphrates River Basin.

\section{STUDY AREA AND DATA Study area}

Eastern Anatolia in Turkey has harsh weather and rough topographical conditions with high snow potential. Foremost precipitation falls as snow and is retained on the ground surface almost half of the year. Snowmelt starts during spring in conjunction to the rise of temperatures which makes considerable increment in streamflows. Transboundary Euphrates River, the longest in southwest Asia, is formed by the union of two major tributaries: Karasu and Murat rising in the highlands of eastern Turkey. Euphrates Basin is the largest in Turkey in terms of drainage area with $127,304 \mathrm{~km}^{2}$ contributing $17 \%$ of the total water potential where most important dam reservoirs (Keban, Karakaya, Atatürk) are located within its boundary. Hence, forecasting the amount and timing of runoff at the headwaters of Euphrates River has great importance for the operation of these reservoirs.

Several studies on satellite snow product validation (Akyurek et al., 2010; Şorman et al., 2007; Sorman and Yamankurt, 2011; Sorman and Beser, 2013) as well as streamflow modeling and forecasting applications (Şensoy et al., 2006; Şorman et al., 2009; Şensoy and Uysal, 2012; Tekeli et al., 2005) are conducted in Karasu Basin as one of the pilot basins selected for various national and international funded projects. Karasu Basin is located within the longitudes $38^{\circ} 58^{\prime} \mathrm{E}$ to $41^{\circ} 39^{\prime} \mathrm{E}$ and latitudes $39^{\circ} 23^{\prime} \mathrm{N}$ to $40^{\circ} 25^{\prime} \mathrm{N}$. It has a drainage area of 10275 $\mathrm{km}^{2}$ and elevation ranges from 1125 to $3487 \mathrm{~m}$. The main land cover types are pasture $(35.0 \%)$, agriculture $(31.5 \%)$, bareland $(27.5 \%)$ and others (urban, forest, lakes etc., 6.0\%).

The location and elevation distribution of Karasu Basin, controlled by stream gaging station E21A019 at Kemah, along with the observation network are provided in Figure 1. A summary of basin topographic properties are given in Table 1 .

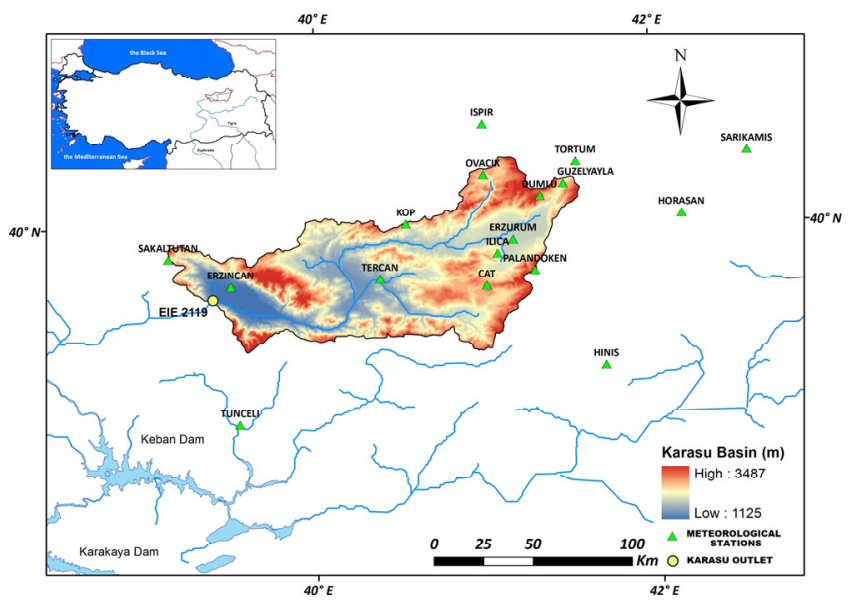

Fig. 1. Location, digital elevation model and observation network of Karasu Basin.

Table 1. Topographic properties of the basin.

\begin{tabular}{|c|ccc|}
\hline Zone & $\begin{array}{c}\text { Elevation range } \\
(\mathrm{m})\end{array}$ & Area $(\%)$ & $\begin{array}{c}\text { Hypsometric mean } \\
\text { elevation }(\mathrm{m})\end{array}$ \\
\hline $\mathrm{A}$ & $1125-1500$ & 10.6 & 1355 \\
\hline $\mathrm{B}$ & $1500-1900$ & 31.7 & 1762 \\
\hline $\mathrm{C}$ & $1900-2300$ & 33.8 & 2097 \\
\hline $\mathrm{D}$ & $2300-2900$ & 22.3 & 2484 \\
\hline $\mathrm{E}$ & $2900-3487$ & 1.6 & 2993 \\
\hline Basin & $1125-3487$ & 100.0 & 1983 \\
\hline
\end{tabular}

\section{Satellite snow cover data}

MODIS satellite images are extensively used for determining areal snow coverage especially in hydrologic modeling. MOD10A1 for Terra and MYD10A1 for Aqua version 5 daily 500-m products are being produced and distributed by the NASA Distributed Active Archive Center (DAAC) located at the National Snow and Ice Data Center (NSIDC). Four MODIS tiles (h20v04, h20v05, h21v04, h21v05) are firstly mosaicked and later subset comprising the mountainous eastern part of Turkey using MODIS Reprojection Tools (MRT) program (https://lpdaac.usgs.gov/tools/modis_reprojection_tool) (Figure 2). The tiled images are then reprojected to World Geodetic Sys- 


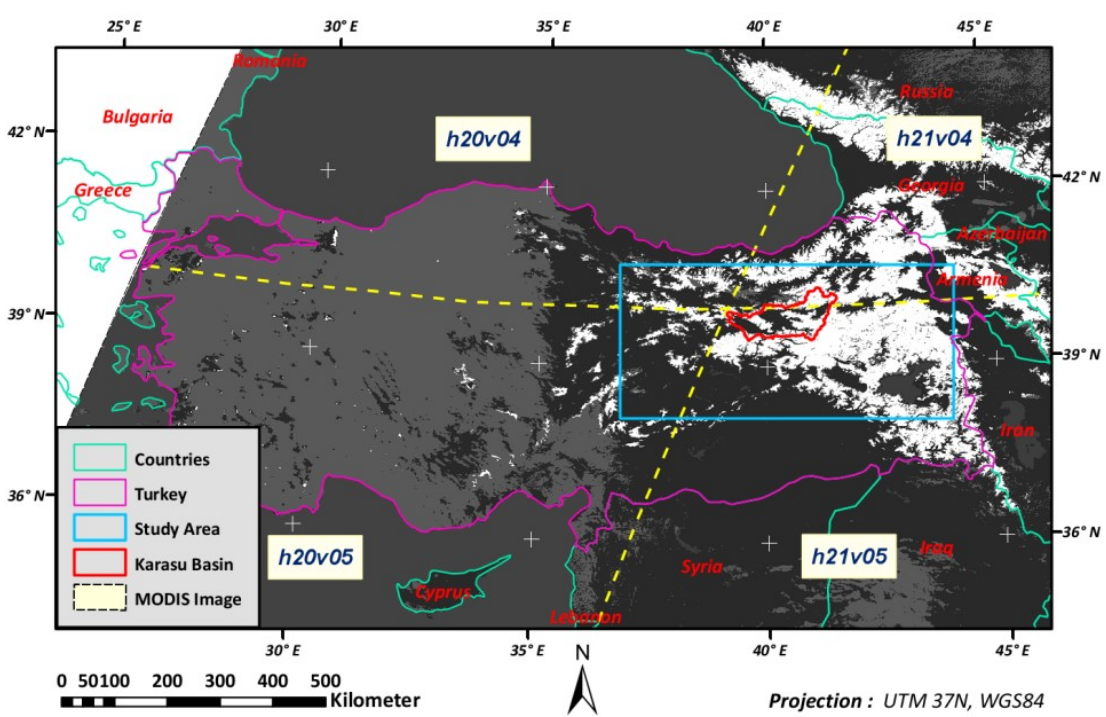

Fig. 2. MODIS tiles and selected study area window.

tem 1984 (WGS84), Universal Transverse Mercator (UTM) Zone 37 with a cell size of 500-m.

The MODIS snow-mapping algorithm is fully automated and is based on the Normalized Difference Snow Index (NDSI) with a set of thresholds (Hall et al., 2002). Based on NDSI and threshold values, snow cover pixels are separated from nonsnowy areas using Eq. (1). Optical satellites are hindered by cloud cover and hence a filtering methodology (combination, temporal, spatial, elevation) (Sorman and Yamankurt, 2011) is applied on a pixel-by-pixel basis to totally eliminate cloud cover and determine binary snow/no snow areas especially during the period of snow melt.

$$
N D S I=\frac{M O D I S_{\text {Band } 4}-M O D I S_{\text {Band } 6}}{M O D I S_{\text {Band } 4}+M O D I S_{\text {Band } 6}}
$$

\section{Hydro-meteorological and snow data}

There are totally 18 climatologic and automated weather operating stations (AWOS) ranging in altitude between 981 and 2937 m (Figure 1). Detrended Kriging (DK) method (Garen et al., 1994; Garen and Marks, 2005) is used to distribute daily average temperature $(\mathrm{T})$ and daily total precipitation $(\mathrm{P})$ in each elevation zone (Table 1) for hydrological modeling.

General trends of total annual precipitation $(\mathrm{P}$ in $\mathrm{cm})$, average annual temperature $\left(\mathrm{T}\right.$ in $\left.{ }^{\circ} \mathrm{C}\right)$, average annual runoff $(\mathrm{Q}$ in $\mathrm{m}^{3} / \mathrm{s}$ ), snow season (Jan-Jun) average snow cover (SCA in \%) of Karasu Basin and maximum Snow Depth (SD in $\mathrm{cm}$ ) at Guzelyayla SNOTEL $(2065-\mathrm{m})$ are given in Figure 3 to provide an insight for hydro-meteorological and snow conditions observed in the last 15 years (2001-2015 water years, 01 Oct-30 Sep). SD values are measured at several automatic snow telemetry (SNOTEL) stations and manual snow courses are conducted twice a month during the winter season. Guzelyayla station, located at $2065-\mathrm{m}$ altitude which is close to the hypsometric mean of the basin, has relatively long continuous records of SD values.

According to data analysis between 2001-2015 years for Karasu Basin, total annual precipitation is $601 \mathrm{~mm} \mathrm{yr}^{-1}$ and average temperature is $4.6^{\circ} \mathrm{C}$. A relatively low-flow period is observed for 2012-2014 water years. Having the sample mean and standard deviation to be much smaller than the population values, extreme events may cause outliers in data analysis and

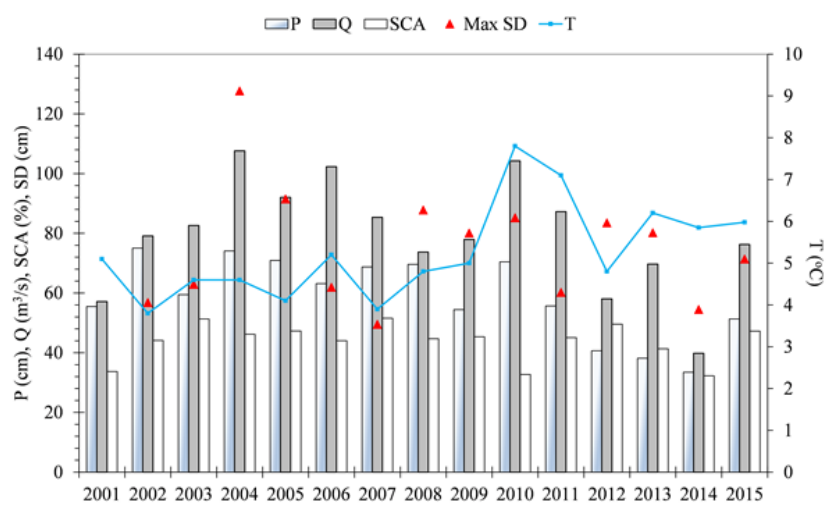

Fig. 3. Hydro-meteorological and snow data.

modeling. Therefore, the Modified Thompson Tau technique is used for verification of streamflow outliers. According to outlier test results for the mean streamflow, 2014 water year is found out as a low-flow outlier. 2004 is another extreme year with relatively high SD and $\mathrm{P}$ that resulted in flooding for some parts of the basin.

\section{METHODOLOGY}

In the most general form, the flow chart of the study is presented in Figure 4. The methodology is presented with four subtitles as; (1) derivation of Snow Probability Maps and classification of Probabilistic Snow Occurrence, (2) extraction of corresponding Probabilistic Snow Depletion Curves (P-SDCs) and Probabilistic Snow Line (P-SL), (3) analysis of P-SDCs and P-SL, (4) Probabilistic Ensemble Streamflow Forecasts (P-ESF) with SRM using P-SDC.

\section{Probability of Snow Occurrence (PSO)}

Spatial patterns of snow occurrence can be derived to explore spatial extent of snow cover in the watershed. "Probability of Snow Occurrence" (PSO) can be defined for each day and pixel as the fraction of MODIS images that are snow covered during the analysis period. The cloud coverage is eliminated from the satellite images with certain filters (Sorman and Yamankurt, 2011) in this study. Therefore, probability of snow 


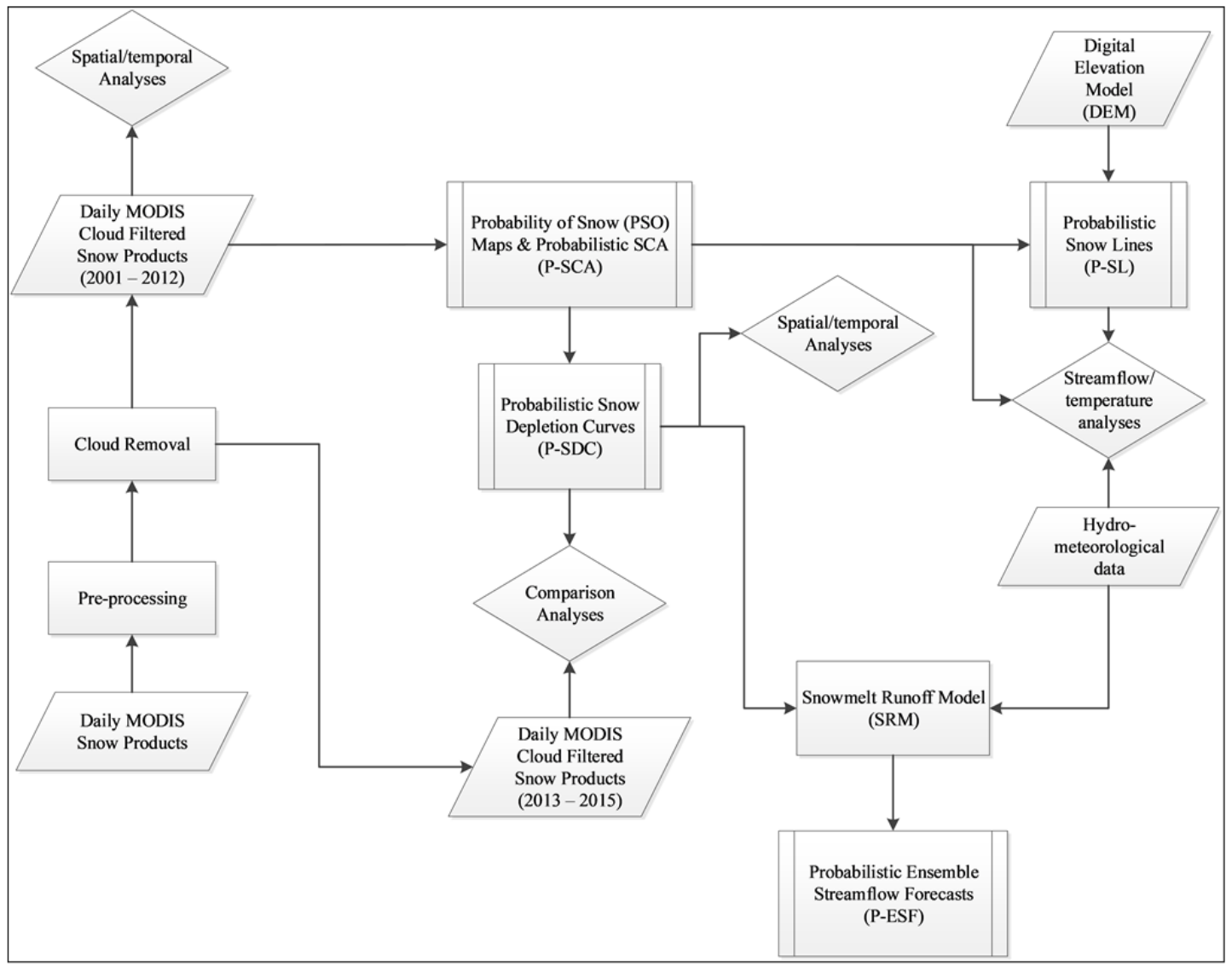

Fig. 4. Flowchart of the study.

distribution is calculated using daily SCA images, for which pixels are classified as snow or no snow, and probability maps are derived accordingly.

The probabilities are classified into six equal classes (Table 2). Zero probability $(\mathrm{P}=0)$ means that there is no snow observation throughout the studied period, and $\mathrm{P}=1$ shows snow coverage within all these years. Accordingly, Snow Depletion Curves (SDCs) are derived indicating snow coverage on each day of the melt season and are frequently required for snowmelt runoff management.

Table 2. Probability classes.

\begin{tabular}{|c|c|}
\hline Classes & Category \\
\hline 0 & No-snow \\
\hline $0.00-0.25$ & Low snow probability \\
\hline $0.25-0.50$ & Average snow probability \\
\hline $0.50-0.75$ & Moderate snow probability \\
\hline $0.75-0.99$ & High snow probability \\
\hline 1 & Full snow \\
\hline
\end{tabular}

\section{Extraction of Probabilistic Snow Line Elevation (P-SL)}

Snow Line (SL) estimates the boundary separating snow covered areas from snow-free areas. The time series of snowline provides an important indicator of snow response to climatic change and allow the prediction of future snow behavior (Tang et al., 2014). Temporal variability of SL elevation is calculated using (probabilistic) snow cover maps. Firstly, a threshold probability is defined and all pixels above this threshold are classified as snow, then probability maps are converted into binary snow cover maps. Afterwards, they are superposed with DEM of the basin and average pixel elevations corresponding to the boundary line are calculated for each day of the year.

\section{Snowmelt Runoff Model (SRM)}

Snowmelt Runoff Model (SRM) (Martinec, 1975; Martinec et al., 2008) is a conceptual model based on a degree-day method to estimate river runoff resulting from snowmelt and rainfall for mountainous basins with the aid of snow cover data. SRM requires daily average air temperature, total precipitation and average snow covered area values as input variables. Based on these input values, SRM computes daily streamflow by Eq. (2):

$$
Q_{n+1}=\left[c_{S n} a_{n}\left(T_{n}+\Delta T_{n}\right) S_{n}+c_{R n} P_{n}\right] \frac{A x 10000}{86400}\left(1-k_{n+1}\right)+Q_{n} k_{n+1}
$$

where $\mathrm{Q}$ is average daily discharge $\left(\mathrm{m}^{3} \mathrm{~s}^{-1}\right)$; $\mathrm{c}$ is runoff coefficient expressing the losses as a ratio (runoff/precipitation) with $\mathrm{c}_{\mathrm{S}}$ referring to snowmelt and $\mathrm{c}_{\mathrm{R}}$ to rain; a is degree-day factor $\left(\mathrm{cm}{ }^{\circ} \mathrm{C}^{-1} \mathrm{~d}^{-1}\right)$; $\mathrm{T}$ is number of degree-days $\left({ }^{\circ} \mathrm{C} \mathrm{d}\right) ; \Delta \mathrm{T}$ is the adjustment by temperature lapse rate; $\mathrm{S}$ is ratio of the snow covered area to the total area; $\mathrm{P}$ is precipitation contributing to runoff $(\mathrm{cm}) ; \mathrm{T}_{\text {CRIT }}$, determines whether this contribution is rainfall $\left({ }^{\circ} \mathrm{C}\right)$; $\mathrm{A}$ is the area of the basin or zone $\left(\mathrm{km}^{2}\right), \mathrm{k}$ is recession coefficient. According to Eq. (2), the daily average discharge on day $\mathrm{n}+1$ is computed by summation of snowmelt and precipitation that contributes to runoff with the discharge on the proceeding day. Eq. (2) is applied to each zone or elevation band (approximately $500 \mathrm{~m}$ ) of the basin when the model is used in a semi-distributed manner and then the discharges are summed up. 
In this study, SRM is re-developed within Delft-FEWS (Flood Early Warning System) (oss.deltares.nl/web/delft-fews) platform (Sensoy et al., 2014a, 2014b; Uysal et al., 2015) and an external automatic optimization methodology is used to estimate the runoff coefficients. After modification and validation of the parameter sets, the basic idea is to use the classified P-SDCs in SRM. Since P-SDCs are generated for selected probability intervals, the cumulative probability alternatives are used in runoff estimation and all the results are presented as an ensemble of streamflows.

For the accuracy assessment, the model is tested with 4 goodness of fit criteria defined as the coefficient of determination $\left(\mathrm{R}^{2}\right)$, Nash-Sutcliffe Efficiency (NSE), Root Mean Square Error (RMSE), Mean Absolute Error (MAE) denoted as:

$$
\begin{aligned}
& R^{2}=\left[\frac{\sum_{t=1}^{N}\left(Q_{m}^{t}-\bar{Q}_{m}\right)\left(Q_{o}^{t}-\bar{Q}_{o}\right)}{\sqrt{\sum_{t=1}^{N}\left(Q_{m}^{t}-\bar{Q}_{m}\right)^{2}} \sqrt{\sum_{t=1}^{N}\left(Q_{o}^{t}-\bar{Q}_{o}\right)^{2}}}\right]^{2} \\
& N S E=1-\frac{\sum_{t=1}^{N}\left(Q_{o}^{t}-Q_{m}^{t}\right)^{2}}{\sum_{t=1}^{N}\left(Q_{o}^{t}-\bar{Q}_{o}\right)^{2}} \\
& R M S E=\sqrt{\frac{\sum_{t=1}^{N}\left(Q_{m}^{t}-Q_{o}^{t}\right)^{2}}{N}}
\end{aligned}
$$
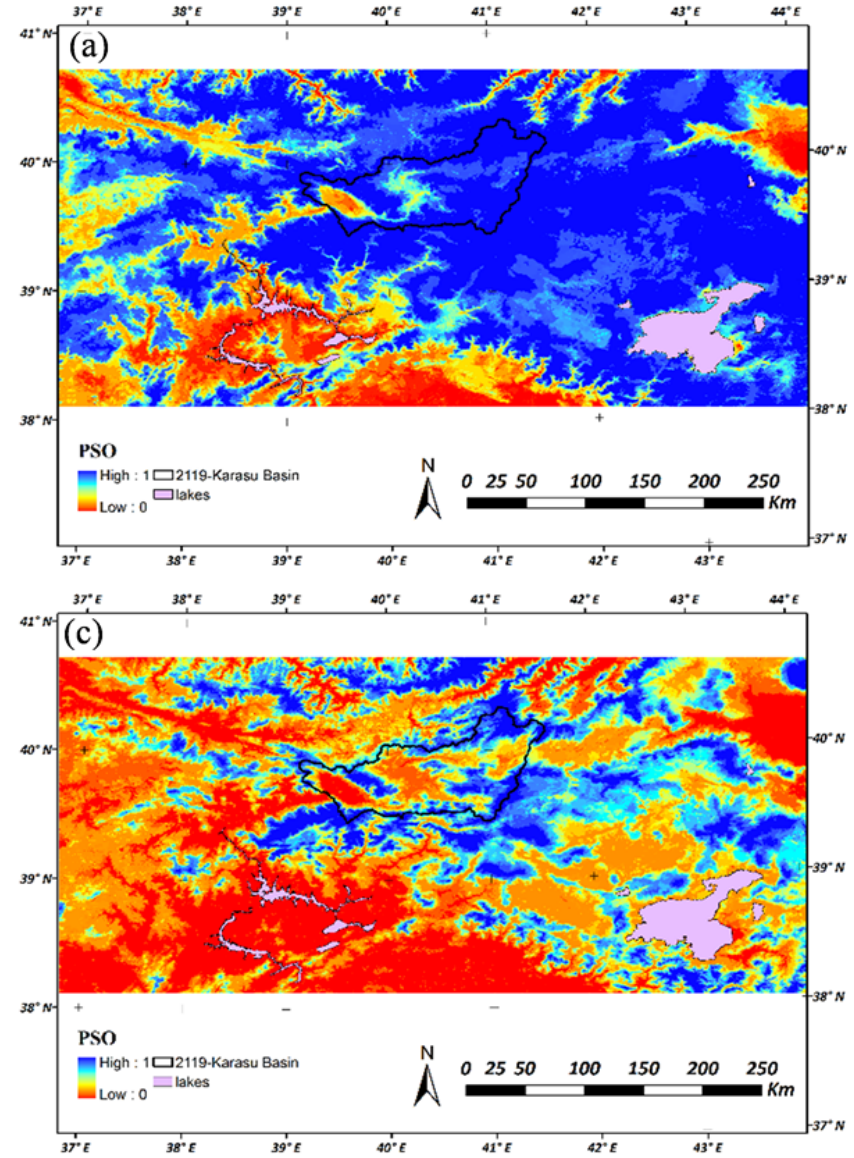

$M A E=\frac{\sum_{t=1}^{N}\left|Q_{o}^{t}-Q_{m}^{t}\right|}{N}$

where $Q_{m}^{t}$ is modeled flows, $Q_{o}^{t}$ is observed flows, $\bar{Q}_{m}$ is average modeled flows, $\bar{Q}_{o}$ is average observed flows, $\mathrm{N}$ is the number of data sets.

\section{RESULTS and DISCUSSION}

Probability maps and Probabilistic Snow Depletion Curves (P-SDCs)

PSO areas are calculated on a pixel-by-pixel basis at daily intervals from January 15 to June 30 using the MODIS binary SCA images during the 2001-2012 period. Figure 5 shows the 15-day areal distribution of PSO (herein also probability maps) across the selected frame during 1 March to 15 April. According to results, there is a rapid melt from 1 March to 1 April due to increase in temperatures and solar radiation. Snow remains only in the upper altitudes through 15 April. A very small portion of the basin is snow covered especially at higher regions and almost all the snow melts until June. After that time, the rest of the snow cover in upper zones is not significant.

Cumulative P-SDCs are presented with box-whisker plots for Karasu Basin in Figure 6a. The graphs are formed with an expected depletion above the selected probabilities. $\mathrm{P}=1$ is the lower band and $\mathrm{P}>0$ is the upper band, a probability range is given for snow coverage through the season. New snowfall creates a sudden increase in the depletion. The frequency of the new snowfall directly related with the selected probability
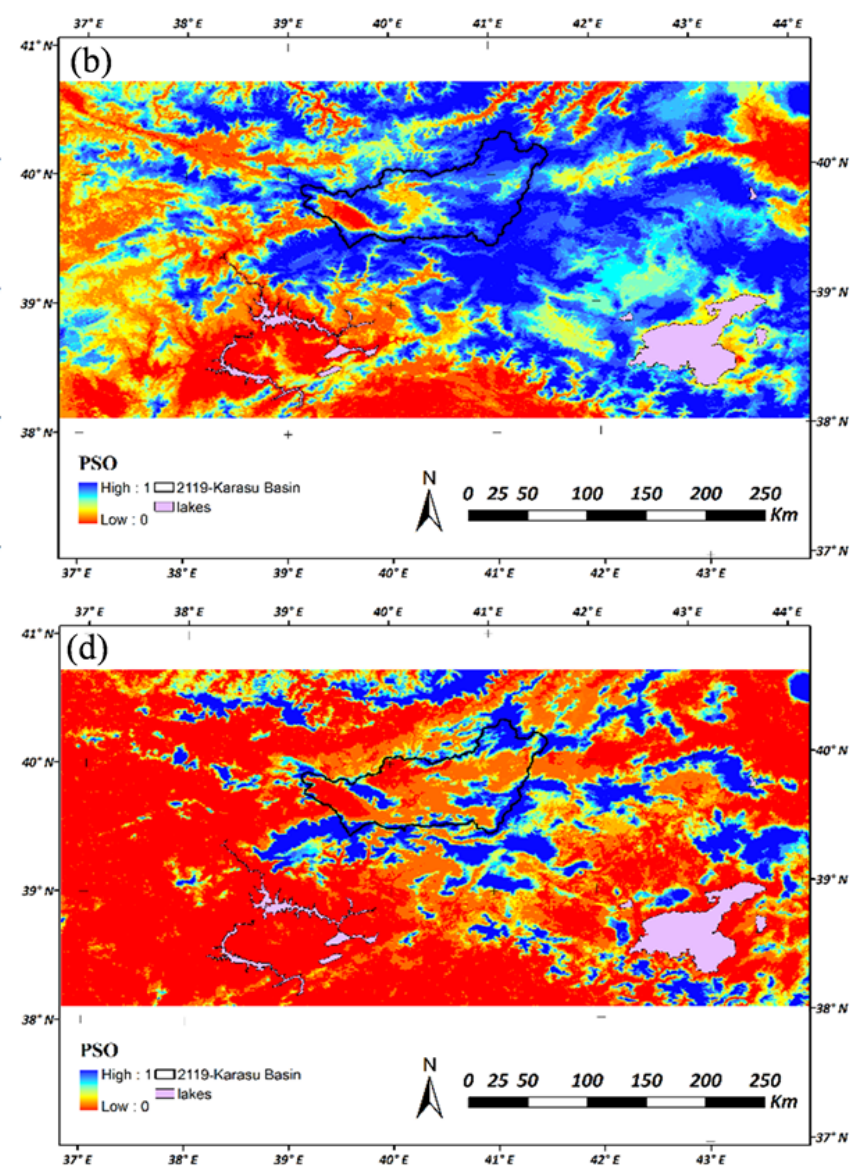

Fig. 5. MODIS Probability of Snow Occurrence maps of selected frame using 2001-2012 data (a) 01 March, (b) 15 March, (c) 01 April, (d) 15 April. 


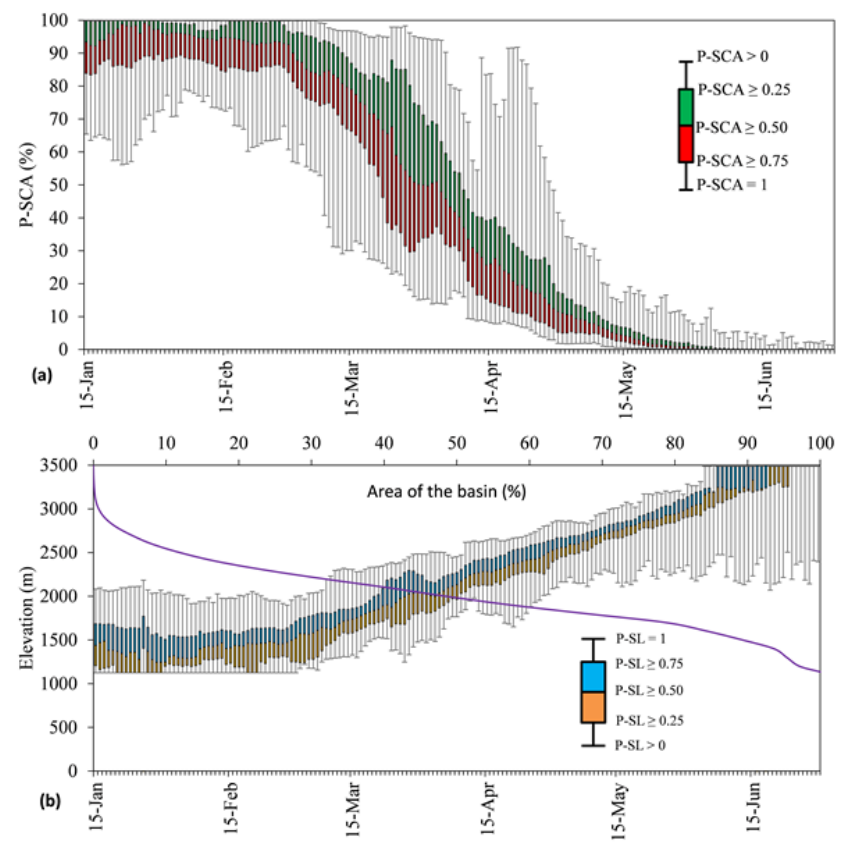

Fig. 6. (a) Cumulative P-SDCs (b) P-SL and hypsometric curve of Karasu Basin.

classes, such that if they occur many times, then the depletion is shifted to an upper probability class. On the other hand, the less frequent new snowfall observed in the lower zones create sudden increases in the $\mathrm{P}>0$ band.

\section{Probabilistic Snow Line (P-SL)}

P-SL is also calculated for each probability class and the results are given in Figure $6 \mathrm{~b}$. The outcomes indicate that the lowest SL elevation and hence the largest snow coverage occurs in the basin during January and February. All P-SL are below the hypsometric mean elevation in these months and this condition lasts till mid-March. P-SL starts to increase at the beginning of March (more than $50 \%$ of the area is snow covered with a $100 \%$ probability) and the median P-SL reaches to maximum elevation of the basin in the first half of June. The PSL has the largest variability particularly through the end of March till the beginning of April. Before and after this period the variability in $25 \%$ and $75 \%$ of SL is almost constant. The median P-SL coincides with hypsometric mean elevation of $2000 \mathrm{~m}$ at the beginning of April (Figure 6b). At the end of the first week of April, $50 \%$ of the area is snow free and almost all percentiles of P-SLs are above the mean elevation of the basin afterwards.

\section{Assessment of probabilistic snow extents Temporal analysis}

Strong seasonal variations in SCA are found with a homogenous snow cover distribution throughout the probability classes.

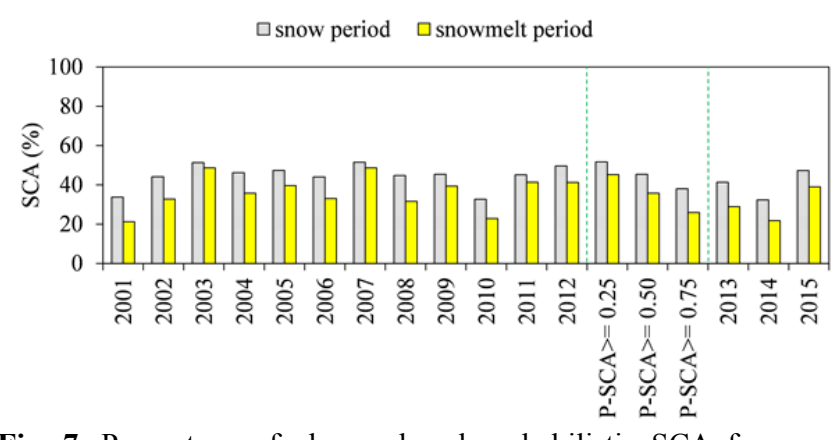

Fig. 7. Percentage of observed and probabilistic SCA for snow (Jan-Jun) and snowmelt (Mar-May) period.

Melting rates of different P-SDCs are calculated based on the slope of the P-SDCs (from Figure 6a). In order to simplify calculations, the slope between $90 \%$ and $10 \%$ coverage of snow is determined. Temporal variations of P-SDC $(0.25-0.75)$ indicate that on average the melting rate is between $1.2-1.4 \%$ day $^{-1}$ for the whole catchment when new snowfall events are discarded in the calculations. The highest rate of depletion $\left(4 \%\right.$ day $\left.^{-1}\right)$ is observed at the highest elevation zone with latest but shortest melting period.

The basin-wide average seasonal snow cover percentages are calculated to detect inter-annual variation in observed daily SCA and P-SCA). Inter-annual variability of the mean snow season (January-June) and snowmelt (March-May) SCA is presented in Figure 7. Observed SCA of 2001-2012 years are used to derive P-SDCs and observed SCA of 2013-2015 years are used to test the derived P-SDCs. It is calculated as the mean of all daily SCA values in the corresponding period. The time series of oscillations in the average SCA shows a high interannual variability, but there is no significant trend in the mean observed SCA for the period 2001-2015. The highest SCA throughout the snow season is observed in 2003 and 2007 (average is around 50\%). The snow poor winters are 2001, 2010 and 2014 (average is around 30\%).

For the 3 years (2013-2015), where SCA data are not included in the probability calculations, an assessment study is carried out to check the performances of derived P-SDCs. The validation performances are given in Table 3 with statistical scores. Observed SDCs have high consistency with $\mathrm{P} \geq 0.50$ and $\mathrm{P} \geq 0.75$ for 2013. SDC shows the highest relationship with high probability classes $(\mathrm{P} \geq 0.75$ and $\mathrm{P}=1)$ which is an indication of low streamflows observed in 2014. 2015 SDC shows average characteristics on streamflow with the highest correlation in $\mathrm{P} \geq 0.25$ and 0.50 for the basin (Table 3 ). Thus, the performance assessment of independent (validation) SCA data set provides convenient results in accordance with Figure 7.

\section{Streamflow analysis}

Snow cover within mountainous areas imposes a definite influence on streamflow and there is a strong relation with SCA and streamflow. The cumulative average of observed discharge

Table 3. Performances of P-SDCs vs MODIS SDCs.

\begin{tabular}{|c|c|c|c|c|c|c|c|c|c|c|c|c|}
\hline \multirow[b]{2}{*}{ Karasu Basin } & \multicolumn{4}{|c|}{2013} & \multicolumn{4}{|c|}{2014} & \multicolumn{4}{|c|}{2015} \\
\hline & $\mathrm{R}^{2}$ & NSE & $\begin{array}{c}\text { RMSE } \\
(\%)\end{array}$ & $\begin{array}{l}\text { MAE } \\
(\%)\end{array}$ & $\mathrm{R}^{2}$ & NSE & RMSE (\%) & MAE (\%) & $\mathrm{R}^{2}$ & NSE & RMSE (\%) & MAE (\%) \\
\hline $\mathrm{P}>0$ & 0.71 & 0.41 & 31.88 & 21.72 & 0.70 & -0.44 & 38.12 & 30.72 & 0.83 & 0.66 & 23.12 & 15.76 \\
\hline $\mathrm{P}>=0.25$ & 0.92 & 0.85 & 16.10 & 10.48 & 0.88 & 0.36 & 25.44 & 19.44 & 0.98 & 0.96 & 7.88 & 5.43 \\
\hline $\mathrm{P}>=0.50$ & 0.96 & 0.95 & 8.95 & 5.46 & 0.93 & 0.67 & 18.09 & 13.54 & 0.98 & 0.98 & 5.58 & 3.03 \\
\hline $\mathrm{P}>=0.75$ & 0.97 & 0.96 & 8.62 & 5.77 & 0.95 & 0.88 & 10.83 & 7.30 & 0.95 & 0.90 & 12.85 & 9.28 \\
\hline $\mathrm{P}=1$ & 0.91 & 0.72 & 22.10 & 15.19 & 0.93 & 0.89 & 10.47 & 6.20 & 0.87 & 0.55 & 26.62 & 20.87 \\
\hline
\end{tabular}




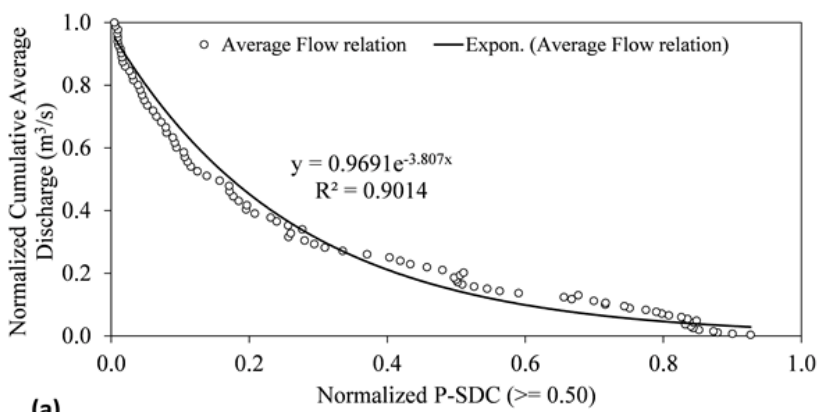

(a)

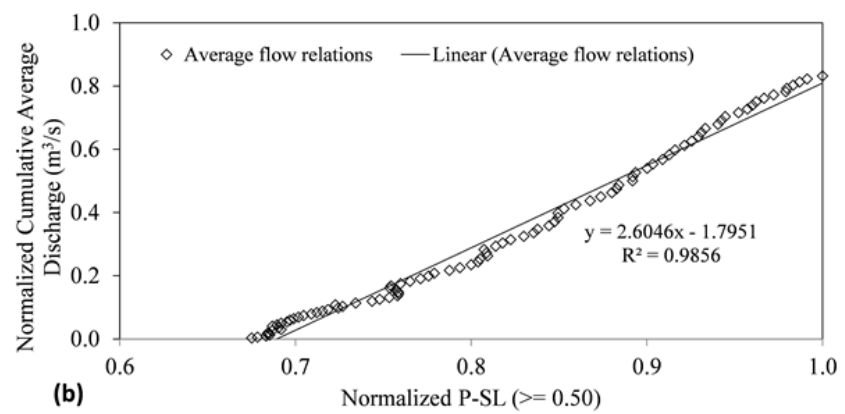

Fig. 8. Relationship between normalized cumulative average discharge and (a) P-SDC (b) P-SL for $\mathrm{P} \geq 0.50$.

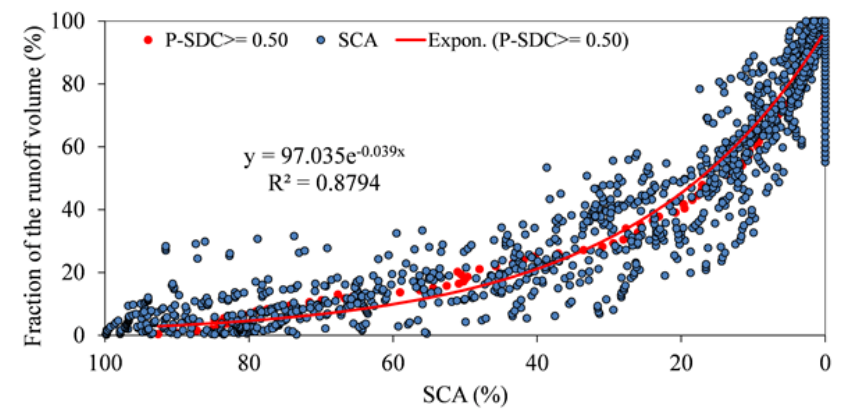

Fig. 9. Fraction of runoff volume and P-SDC relationship.

values (2001-2012) in March-May snowmelt period are normalized and their relation with cumulative P-SDC $(\mathrm{P} \geq 0.50)$ is analyzed for Karasu Basin (Figure 8a). There is a significant negative trend between SCA and streamflow, the decrease of P-SCA with time causes an exponential depletion of runoff in mountainous basins. The same analysis conducted for each year confirms this relationship. Exponential relationship implies that late decrease in SCA leads to higher changes in runoff than early decrease in SCA of the same magnitude. During melting, the snow line retreats from the lower altitude to higher altitude and consequently SCA in the basin is reduced. The retreat rate is increased in the later part of the melt season due to higher depth of snow at high altitudes. As a result, the highest coefficient of determination for exponential relationship in terms of Pearson $\mathrm{R}^{2}$ is observed as 0.90 corresponding to $\mathrm{P} \geq 0.50$. Moreover, the cumulative normalized runoff relationships are also analyzed in relation with P-SL $(\mathrm{P} \geq 0.50)$ (Figure $8 \mathrm{~b})$ for 2001-2012 March-May periods and it seems that runoff increases linearly with the snow line.

The correlation analyses between SCA and the proportion of runoff during snowmelt period indicates that the increase of runoff volume ratio is closely related to the SCA changes (Marcil et al., 2016). Therefore, one of the final analysis is the correlation between SCA (conventional and probabilistic) and runoff volume fraction. The fraction of runoff volume is also determined for the melting period, March-May. The daily fractions of runoff volume are computed as the ratio of the daily cumulative runoff volume to the total runoff volume and then they are converted to percent values. A scatter plot of SCA (SCA and percent runoff volume fraction of each year) and PSCA (probabilistic SCA and percent runoff volume fraction of average runoff) for Karasu Basin is shown in Figure 9, for average runoff values over a 12 year (2001-2012) period. As expected, the fraction of runoff volume increases with a decrease of the snow areal extent. The runoff volume is expected to increase as the snow cover depletes to the upper elevations in the basin. An exponential function is found to be the best fit to the data and results indicate a robust correlation between SCA and runoff with $\mathrm{R}^{2}=0.88$ as presented in Figure 9 .

\section{Temperature analysis}

It is very essential to understand the relationship between P-SDC / P-SL and temperature since snow ablation processes are strongly controlled by air temperature. The average daily temperatures are calculated for the snowmelt period (MarchMay) of 2001-2012 and scattered with respect to corresponding P-SCA (Figure 10a) and P-SL (Figure 10b). The high positive correlations between P-SDC / P-SL and temperature is the robust evidence of temperature effect on snow extent. The rising temperature increases snow melting, thus causes higher SL and lower SCA.

Assuming that snowmelt is linearly related with temperature, one can conclude that SCA and cumulative temperatures should have an exponential relationship. Since cumulative negative temperatures disturb the exponential relationship for the initial period of the melt season, instead of cumulative temperatures, daily average temperatures are used in the analysis with a linear relation. These relations might also help to determine possible SCA values in case of a gap in the data series (ground data) or cloudy periods (satellite data).

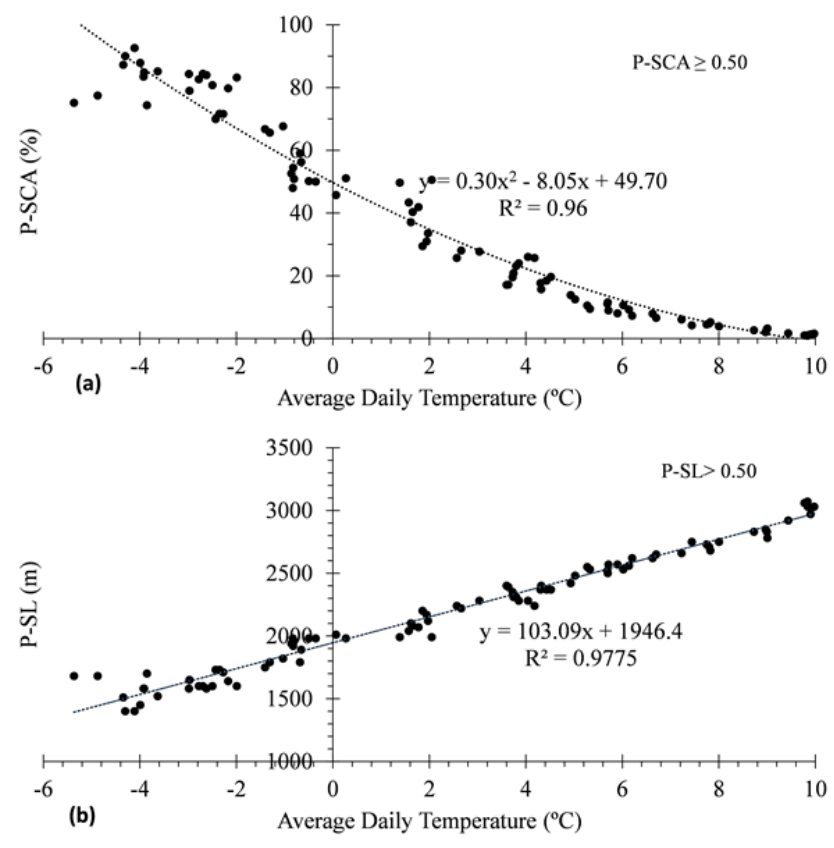

Fig. 10. Relationship with average daily temperature and (a) P-SDC, (b) P-SL for $\mathrm{P} \geq 0.50$. 


\section{Probabilistic Ensemble Streamflow Forecasts (P-ESF)}

Snowmelt Runoff Model, SRM, is implemented to produce Probabilistic Ensemble Streamflow Forecasts (P-ESF) from the derived probability maps. The watershed is divided into subelevation zones (Table 1) to improve modeling accuracy. The data is split into calibration and validation stages; calibration data is used to optimize the model parameters from 2002 to 2008 water years, validation is done for the remaining four years 2009 to 2012. The Nash-Sutcliffe goodness-of-fit coefficient, NSE, is used to determine the fit between modeled and observed flows. The observed and modeled runoff values are presented for Karasu Basin in Figure 11 and the performance of the model is summarized consecutively in Table 4 . The accuracy of SRM model to mimic streamflow is high in terms of magnitude, trend and timing of the discharges considering relatively higher NSE value of 0.85 for the calibration period. NSE is sensitive to extreme values, thus, high overestimation of model simulations for 2010 reduces the model accuracy to some extent (Table 4).

Table 4. Model performance.

\begin{tabular}{|c|c|c|c|}
\hline $\begin{array}{c}\text { Period } \\
\text { (Water Year) }\end{array}$ & $\mathrm{R}^{2}$ & $\mathrm{NSE}$ & $\mathrm{RMSE}\left(\mathrm{m}^{3} / \mathrm{s}\right)$ \\
\hline $\begin{array}{c}\text { Calibration } \\
(2002-2008)\end{array}$ & 0.86 & 0.85 & 32.62 \\
\hline $\begin{array}{c}\text { Validation } \\
(2009-2012)\end{array}$ & 0.84 & 0.73 & 34.59 \\
\hline
\end{tabular}

The model uses three major variables of daily average Snow Cover Area (SCA), average temperature (T) and total precipitation $(\mathrm{P})$ as model inputs. Using different daily SCA patterns (P$\mathrm{SCA}$ ) with same $\mathrm{P}$ and $\mathrm{T}$ time series in the model gives different runoff values and these are called as ensembles. Therefore, the forecasting procedure is based on the hydrological model (SRM) that allows for the calculation of probabilistic ensemble streamflow (P-ESF) values for the period of 2013-2015 with two types of forcing data: observed snow cover area data on the basis of conventional SCA by MODIS (MODIS-SDC) and probabilistic SCA data by P-SDC for a range of probabilities. The model is applied by means of the perfect meteorological forecast data set (observed precipitation and temperature variables) and without any updating technique to focus on the direct effect of SDCs on runoff dynamics. The results are depicted by hydrographs in Figure 12 and goodness of fit statistics are given in Table 5 .

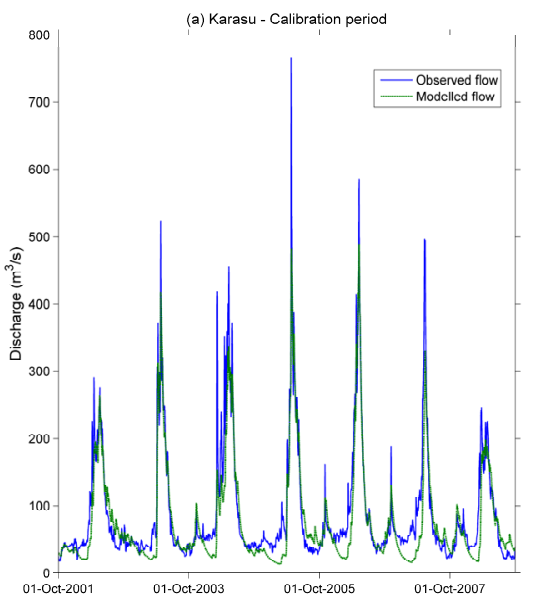

Table 5. P-ESF goodness of fit statistics, 2013-2015.

\begin{tabular}{|c|c|c|c|c|c|}
\hline Water Year & Simulation & $\mathrm{R}^{2}$ & NSE & $\begin{array}{l}\text { RMSE } \\
\left(\mathrm{m}^{3} / \mathrm{s}\right)\end{array}$ & $\begin{array}{l}\mathrm{MAE} \\
\left(\mathrm{m}^{3} / \mathrm{s}\right)\end{array}$ \\
\hline \multirow{5}{*}{$\stackrel{m}{\stackrel{n}{\sim}}$} & P-SDC $\geq 0.25$ & 0.68 & -5.65 & 157.24 & 102.48 \\
\hline & P-SDC $\geq 0.50$ & 0.65 & -0.75 & 80.59 & 56.81 \\
\hline & P-SDC $\geq 0.75$ & 0.60 & 0.47 & 44.23 & 29.80 \\
\hline & $\mathrm{P}-\mathrm{SDC}=1.00$ & 0.35 & -0.21 & 67.04 & 46.23 \\
\hline & MODIS-SDC & 0.79 & 0.76 & 29.56 & 19.87 \\
\hline \multirow{5}{*}{$\underset{d}{\stackrel{\nabla}{d}}$} & P-SDC $\geq 0.25$ & 0.59 & -146.77 & 189.94 & 140.26 \\
\hline & P-SDC $\geq 0.50$ & 0.66 & -52.78 & 114.58 & 86.28 \\
\hline & P-SDC $\geq 0.75$ & 0.69 & -12.51 & 57.43 & 44.39 \\
\hline & $\mathrm{P}-\mathrm{SDC}=1.00$ & 0.58 & -1.40 & 24.22 & 17.21 \\
\hline & MODIS-SDC & 0.68 & -6.19 & 41.91 & 30.87 \\
\hline \multirow{5}{*}{$\stackrel{n}{\stackrel{n}{d}}$} & P-SDC $\geq 0.25$ & 0.97 & 0.81 & 36.67 & 26.75 \\
\hline & P-SDC $\geq 0.50$ & 0.93 & 0.93 & 22.85 & 15.27 \\
\hline & P-SDC $\geq 0.75$ & 0.85 & 0.73 & 43.52 & 29.31 \\
\hline & P-SDC $=1.00$ & 0.81 & 0.60 & 52.66 & 35.62 \\
\hline & MODIS-SDC & 0.93 & 0.86 & 30.90 & 22.70 \\
\hline
\end{tabular}

It is interesting to note that each year has a different snow trend and observed runoff values show correlation with one of the derived cumulative probability ranges (Figure 12, Tables 3 and 5). The results indicate that; i) 2013 water year; this year can be classified as a dry year in terms of average rainfall but normal in regard to snowfall (snow depth) and discharges comparing 15-year averages of basin variables. Simulation with observed SDC gives NSE of 0.75 with an underestimation of the early runoff peak observed in 18 March. Either model parameters or rainfall representation (or both) might have caused this underestimation in the peak simulation. $\mathrm{P} \geq 0.75$ best suites to 2013 runoff hydrograph in general (NSE $=0.47$ ), however there is a better agreement by $\mathrm{P} \geq 0.50$ for the first runoff peak, ii) 2014 water year; it is a low-flow outlier year with very low precipitation and snow depth. Even the simulation model performance with observed SDC is low in terms of NSE (with relatively high $\mathrm{R}^{2}$ ) in this year. There would be several reasons for this, one of which might be the rather high runoff coefficients (such a low-flow condition precipitation and runoff was not used in the calibration data set) when P-ESF analysis is carried out. Least snow probability $(\mathrm{P}=1)$ seems to best coincide with the observed runoff giving almost similar performance, iii) 2015 water year; model results give high

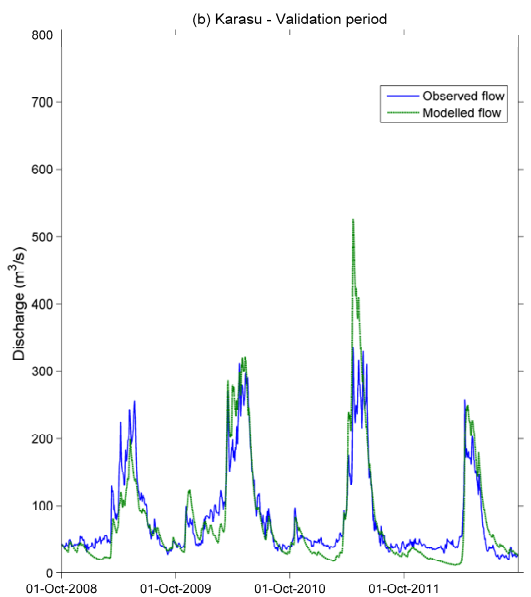

Fig. 11. SRM results in comparison to observed flows (a) Calibration period (2002-2008) (b) Validation period (2009-2012). 

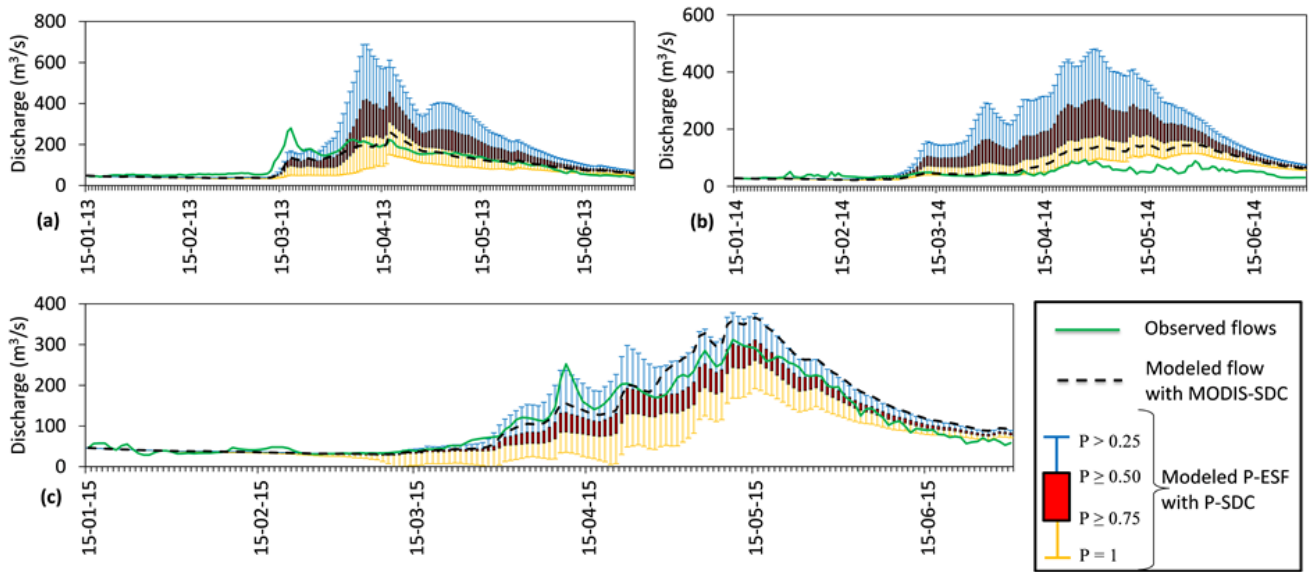

Fig. 12. SRM P-ESF results using P-SDCs (a) 2013, (b) 2014, (c) 2015.

model performance both using conventional observed SDC and P-SDC with NSE of 0.86 and 0.93 , respectively. These results are most probably achieved due to average runoff and precipitation conditions. Simulation with $\mathrm{P} \geq 0.50$ provides quite a good match with the observed runoff values for 2015 except for the first peak where $\mathrm{P} \geq 0.25$ provides better estimates (Figure 12 and Table 5). All of the results are highly coherent with the outcomes of the assessments on conventional SCA and P-SCA for the melting periods of 2013-2015, therefore, the correspondence is high with Table 3 . The results indicate that $\mathrm{P}=1$ and/or $\mathrm{P} \geq 0.75$ work better for dry years and $\mathrm{P}=0$ and/or $\mathrm{P} \geq$ 0.25 can be chosen for wet years. A choice of P-SDC for a forecasting period could be determined according to the latest SCA and SWE states if available. A higher consistency can also be achieved if an additional update or assimilation procedure is implemented throughout the streamflow forecasting period.

\section{CONCLUSIONS}

Quantifying snowmelt has been a challenging aspect of hydrology with data and model uncertainties due to harsh topography and atmospheric conditions in a data scarce region. The research makes significant contributions to this field providing a valuable methodology to better understand snow cover dynamics and aid in probabilistic runoff forecasting.

Although ground-based measurements are generally accurate, stations are often sparsely located and the measurements do not adequately represent the spatial distribution of the snow extent. Remote sensing provides an ideal tool to observe status and dynamics of snow coverage whereby dedicated satellite snow data have an extensively increasing potential in water resources. An accurate information on the temporal and spatial depletion of snowpack can be efficiently implemented for operational runoff forecasting. Therefore, the study is intended as a precedent toward using satellite SCA products to assess snow cover assortment producing P-SDC and P-SL for better understanding of snow climatology and characteristics. Moreover, the value of making use of P-SDCs in hydrological modeling as well as generating probabilistic ensembles in operational runoff estimation for a mountainous catchment is presented. Forcing the hydrological model with P-SDCs shows promising results in probabilistic streamflow prediction.

Snow cover depletion curves are derived from 2001 to 2012 using MODIS satellite images that provide widely-used operational snow products with fine temporal resolution. Generalization of processed satellite snow cover images as probabilistic snow cover depletion (P-SDC) and snow line (P-SL) are the main features representing the snow cover characteristics of regions over mountainous domains. It is also shown that PSDCs are useful in generating probabilistic ensemble streamflow forecasts (P-ESF) which is carried out for 2013-2015 snowmelt periods. As a conclusion, both the correlation established between the position of the snow depletion curve (or snowmelt line) and the value and/or timing of runoff, as well as $\mathrm{P}-\mathrm{ESF}$ results based on the derived P-SDCs can guide decisionmakers responsible for water resources management in the region. Since the proposed framework is a generic one, it can easily be adapted to other scarce networks or even ungaged mountainous watersheds dominated by snow accumulation and melt.

The forecasts can further be improved with the selection of suitable P-SDC through near real time SCA observations over the basin and also considering state updating of the hydrological model. On the other hand, any variation in a characteristic depletion curve over the decades could point out a climate change which would further indicate a reassessment in water resources planning.

Acknowledgement. This study was partly funded by TÜBİTAK (The Scientific and Technical Research Council of Turkey) (Project No: 113Y075) and Anadolu University Scientific Research Fund (Project No: 1306F113). The authors wish to thank General Directorate of Meteorology (MGM) and State Hydraulic Works (DSI) for data contribution.

\section{REFERENCES}

Akyurek, Z., Hall, D.K., Riggs, G.A., Sorman, A.U., 2010. Evaluating the utility of the ANSA blended snow cover product in the mountains of eastern Turkey. International Journal Remote Sensing, 31, 14, 3727-3744.

Arsenault, K.R., Houser, P.R., De Lannoy, G.J., 2014. Evaluation of the MODIS snow cover fraction product. Hydrol. Process., 28, 3, 980-998.

Brander, D., Seidel, K., Zurflüh, M., Huggel, C., 2000. Snow cover duration maps in alpine regions from remote sensing data. In Proceedings of EARSeL-SIG-Workshop Land Ice and Snow, Dresden/FRG, pp 292-296.

Cornwell, E., Molotch, N.P., McPhee, J., 2016. Spatio-temporal variability of snow water equivalent in the extra-tropical Andes Cordillera from distributed energy balance modeling and remotely sensed snow cover. Hydrology Earth System Science, 20, 411-430.

Crawford, C.J., 2015. MODIS Terra Collection 6 fractional 
snow cover validation in mountainous terrain during spring snowmelt using Landsat TM and ETM. Hydrologic Processes, 29, 1, 128-138.

Da Ronco, P., De Michele, C., 2014. Cloudiness and snow cover in Alpine areas from MODIS products. Hydrol. Earth Syst. Sci. Discuss., 11, 3967-4015.

Day, A.C., 2013. Modeling snowmelt runoff response to climate change in the Animas River Basin. Colorado. Journal of Geology and Geoscience, 2, 110.

Duethmann, D., Peters, J., Blume, T., Vorogushyn, S., Guntner, A., 2014. The value of satellite-derived snow cover images for calibrating a hydrological model in snow-dominated catchments in Central Asia. Water Resources Research, 50, 3, 2002-2021. DOI: 10.1002/2013WR014382.

Finger, D., Vis, M., Huss, M., Seibert, J., 2015. The value of multiple data set calibration versus model complexity for improving the performance of hydrological models in mountain catchments. Water Resources Research, 51, 4, 19391958.

Forsythe, N., Kilsby, C.G., Fowler, H.J., Archer, D.R., 2012. Assessment of runoff sensitivity in the upper Indus basin to interannual climate variability and potential change using MODIS satellite data products. Mountain Research and Development, 32, 1, 16-29.

Franz, K.J., Karsten, L.R., 2013. Calibration of a distributed snow model using MODIS snow covered area data. J. Hydrol., 494, 160-175.

Gafurov, A., Bárdossy, A., 2009. Cloud removal methodology from MODIS snow cover product. Hydrology and Earth System Sciences, 13, 7, 1361-1373.

Gafurov, A., Vorogushyn, S., Farinotti, D., Duethmann, D., Merkushkin, A., Merz, B., 2015. Snow-cover reconstruction methodology for mountainous regions based on historic in situ observations and recent remote sensing data. The Cryosphere, 9, 2, 451-463.

Gao, Y., Xie, H., Lu, N., Yao, T., Liang, T., 2010. Toward advanced daily cloud-free snow cover and snow water equivalent products from Terra-Aqua MODIS and Aqua AMSR-E measurements. J. Hydrol., 385, 1, 23-35.

Garen, D.C., Johnson, G.L., Hanson, C.L., 1994. Mean areal precipitation for daily hydrologic modeling in mountainous regions. Water Resour. Bull., 30, 3, 481-491.

Garen, D.C., Marks, D., 2005. Spatially distributed energy balance snowmelt modelling in a mountainous river basin: estimation of meteorological inputs and verification of model results. J. Hydrol., 315, 126-153.

Gascoin, S., Hagolle, O., Huc, M., Jarlan, L., Dejoux, J.F., Szczypta, C., Marti, R., Sánchez, R., 2015. A snow cover climatology for the Pyrenees from MODIS snow products. Hydrology and Earth System Sciences, 19, 5, 2337-2351.

Gómez-Landesa, E., Rango, A., 2002. Operational snowmelt runoff forecasting in the Spanish Pyrenees using the snowmelt runoff model. Hydrol. Process., 16, 1583-1591.

Hall, D.K., Riggs, G.A., Salomonson, V.V., DiGirolamo, N.E., Bayr, K.J., 2002. MODIS snow-cover products. Remote sensing of Environment, 83, 1, 181-194.

Hall, D.K., Riggs, G.A., 2007. Accuracy assessment of the MODIS snow products. Hydrol. Process., 21, 12, 15341547.

He, Z.H., Parajka, J., Tian, F.Q., Blöschl, G., 2014. Estimating degree-day factors from MODIS for snowmelt runoff modeling. Hydrology Earth System Science, 18, 4773-4789.

Huang, X.D., Liang, T.G., Zhang, X.T., Guo, Z.G., 2011. Validation of MODIS snow cover products using Landsat and ground measurements during the 2001-2005 snow seasons over northern Xinjiang, China. International Journal of Remote Sensing, 32, 1, 133-52.

Jain, S.K., Goswami, A., Saraf, A.K., 2010a. Snowmelt runoff modelling in a Himalayan basin with the aid of satellite data. Int. J. Remote Sens., 31, 24, 6603-6618.

Jain, S.K., Goswami, A., Saraf, A.K., 2010b. Assessment of snowmelt runoff using remote sensing and effect of climate change on runoff. Water Resour. Manag., 24, 9, 1763-1777.

Jain, S.K., Thakural, L.N., Singh, R.D., Lohani, A.K., Mishra, S.K., 2011. Snow cover depletion under changed climate with the help of remote sensing and temperature data. Nat. Hazards, 58, 3, 891-904.

Krajčí, P., Holko, L., Perdigão, R.A., Parajka, J., 2014. Estimation of regional snowline elevation (RSLE) from MODIS images for seasonally snow covered mountain basins. J. Hydrol., 519, 1769-1778.

Krajčí, P., Holko, L., Parajka, J., 2016. Variability of snow line elevation, snow cover area and depletion in the main Slovak basins in winters 2001-2014. J. Hydrol. Hydromech., 64, 1, $12-22$.

Lee, S.W., Klein, A.G., Over, T.M., 2005. A comparison of MODIS and NOHRSC snow-cover products for simulating stream flow using the Snowmelt Runoff Model. Hydrol. Process., 19, 15, 2951-2972.

Li, X.G., Williams, M.W., 2008. Snowmelt runoff modelling in an arid mountain watershed, Tarim Basin, China. Hydrological Processes, 22, 19, 3931-3940.

López-Burgos, V., Gupta, H.V., Clark, M., 2013. Reducing cloud obscuration of MODIS snow cover area products by combining spatio-temporal techniques with a probability of snow approach. Hydrology and Earth System Sciences, 17, 5, 1809-1823.

Marcil, G.K., Leconte, R., Trudel, M., 2016. Using remotely sensed MODIS snow product for the management of reservoirs in a mountainous Canadian watershed. Water Resources Management, 30, 8, 2735-2747.

Martinec, J., 1975. Snowmelt-runoff model for stream flow forecasts. Nord. Hydrol., 6, 145-154.

Martinec, J., Rango, A., Roberts, R., 2008. Snowmelt runoff model (SRM) user's manual. New Mexico State University, College of Agriculture and Home Economics, Las Cruces, New Mexico, USA.

Maurer, E.P., Rhoads, J.D., Dubayah, R.O., Lettenmaier, D.P., 2003. Evaluation of the snow-covered area data product from MODIS. Hydrol. Process., 17, 1, 59-71.

Panday, P.K., Williams, C.A., Frey, K.E., Brown, M.E., 2014. Application and evaluation of a snowmelt runoff model in the Tamor River basin, Eastern Himalaya using a Markov Chain Monte Carlo (MCMC) data assimilation approach. Hydrol. Process., 28, 21, 5337-5353.

Parajka, J., Blöschl, G., 2008. The value of MODIS snow cover data in validating and calibrating conceptual hydrologic models. J. Hydrol., 358, 3, 240-258.

Parajka, J., Pepe, M., Rampini, A., Rossi, S., Blöschl, G., 2010. A regional snow-line method for estimating snow cover from MODIS during cloud cover. J. Hydrol., 381, 3, 203212.

Raleigh, M.S., Rittger, K., Moore, C.E., Henn, B., Lutz, J.A., Lundquist, J.D., 2013. Ground-based testing of MODIS fractional snow cover in subalpine meadows and forests of the Sierra Nevada. Remote Sensing of Environment, 128, 44-57.

Richer, E.E., 2009. Snowmelt runoff analysis and modelling for the upper cache La Poudre River basin, Colorado. MsS Thesis, Colorado State University, Fort Collins, USA. 
Riggs, G.A., Hall, D.K., Salomonson, V.V., 2006. MODIS Snow Products User Guide to Collection 5. http://modissnow-ice.gsfc.nasa.gov/?c=userguides. (Accessed Feb 2018)

Sensoy, A., Parajka, J., Coskun, C., Sorman, A., Ertas, C., 2014a. Quantifying the performance of two conceptual models for snow dominated catchments in Austria and Turkey. In: EGU General Assembly Conference Abstracts, 16, p. 10421.

Sensoy, A., Schwanenberg, D., Sorman, A., Akkol, B., Alvarado Montero, R., Uysal, G., 2014b, May. Assimilating HSAF and MODIS Snow Cover Data into the Conceptual Models HBV and SRM. In: EGU General Assembly Conference Abstracts, 16, p. 10240.

Singh, P., Bengtsson, L., Berndtsson, R., 2003. Relating air temperatures to the depletion of snow covered area in a Himalayan basin. Nord. Hydrol., 34, 4, 267-280.

Sorman, A.A., Yamankurt, E., 2011. Modified satellite products on snow covered area in upper Euphrates basin, Turkey. Geophys Res. Abstr., 13, EGU2011-7887.

Sorman, A.U., Beser, O., 2013. Determination of snow water equivalent over the eastern part of Turkey using passive microwave data. Hydrol. Process., 27, 14, 1945-1958.

Şensoy, A., Şorman, A.A., Tekeli, A.E., Şorman, A.Ü., Garen, D.C., 2006. Point-scale energy and mass balance snowpack simulations in the upper Karasu basin, Turkey. Hydrol. Process., 20, 4, 899-922.

Şensoy, A., Uysal, G., 2012. The value of snow depletion forecasting methods towards operational snowmelt runoff estimation using MODIS and Numerical Weather Prediction Data. Water Resour. Manag., 26, 12, 3415-3440.

Şorman, A.A., Şensoy, A., Tekeli, A.E., Şorman, A.Ü., Akyürek, Z., 2009. Modelling and forecasting snowmelt runoff process using the HBV model in the eastern part of Turkey. Hydrol. Process., 23, 7, 1031-1040.

Şorman, A.Ü., Akyürek, Z., Şensoy, A., Şorman, A.A., Tekeli, A. E., 2007. Commentary on comparison of MODIS snow cover and albedo products with ground observations over the mountainous terrain of Turkey. Hydrol. Earth Syst. Sc., 11, 4, 1353-1360.

Tahir, A.A., Chevallier, P., Arnaud, Y., Neppel, L., Ahmad, B., 2011. Modeling snowmelt-runoff under climate scenarios in the Hunza River Basin, Karakoram Range, Northern Pakistan. J. Hydrol., 409, 104-117.

Tang, Z., Wang, J., Li, H., Yan, L., 2013. Spatiotemporal changes of snow cover over the Tibetan plateau based on cloud-removed moderate resolution imaging spectraradiometer fractional snow cover product from 2001 to 2011. Journal of Applied Remote Sensing, 7, 1, 073582.

Tang, Z., Wang, J., Li, H., Liang, J., Li, C., Wang, X., 2014. Extraction and assessment of snowline altitude over the Tibetan plateau using MODIS fractional snow cover data (2001 to 2013). Journal of Applied Remote Sensing, 8, 084689.

Tekeli, A.E., Akyürek, Z., Şorman, A.A., Şensoy, A., Şorman, A.Ü., 2005. Using MODIS snow cover maps in modeling snowmelt runoff process in the eastern part of Turkey. Remote Sens. Environ., 97, 2, 216-230.

Tekeli, A.E., Sönmez, I., Erdi, E., 2016. Snow-covered area determination based on satellite-derived probabilistic snow cover maps. Arabic Journal of Geosciences, 9, 198.

Tong, J., Déry, S.J., Jackson, P.L., 2009. Interrelationships between MODIS/Terra remotely sensed snow cover and the hydrometeorology of the Quesnel River Basin, British Columbia, Canada. Hydrology and Earth System Sciences, 13, $8,1439-1452$.

Uysal, G., Akkol, B., Ertaş, C., Çoşkun, C., Şorman, A., Şensoy, A., Schwanenberg, D., 2015. Developing an Operational Hydrologic Forecast System using EPS and Satellite Data in Mountainous Basins of Turkey, DSD-2015, Delft Software Days, Delft, The Netherlands.

Wang, M., Son, S., Shi, W., 2009. Evaluation of MODIS SWIR and NIR-SWIR atmospheric correction algorithms using SeaBASS data. Remote Sensing of Environment, 113, 3, 635-644.

Wang, X., Xie, H., 2009. New methods for studying the spatiotemporal variation of snow cover based on combination products of MODIS Terra and Aqua. J. Hydrol., 371, 1, 192-200.

Received 7 August 2017 Accepted 22 February 2018 